\title{
Semantics Study of Figurative Meaning in Indonesian Proverbs
}

\author{
Eva Chairani \\ Post Graduate School \\ English Applied Linguistic Universitas Negeri Medan \\ Medan, Sumatera Utara \\ eva.womanheaven@gmail.com
}

\author{
Sri Minda Murni \\ Post Graduate School \\ English Applied Linguistics Universitas Negeri Medan \\ Medan, Sumatera Utara
}

\begin{abstract}
Proverb is one of many ways for people in communication. it is short, clear, containing wise, culture in metaphorical form in order to make it easy to memorize. Proverb also considered as people cognition in responding experience, point of view and observation in surrounding. Linguistics and people cognition play vital role for people in constructing proverbs and it also depends on their natural background knowledge. figurative meaning as a component which find in proverbs gives unexpected orientation toward subject matter. Response concerning the role of figurative meaning within proverb evokes the willing to know what the figurative meaning within proverbs present for. By applying Cognitive semantics approach as a base of revealing the mental process in interpreting proverbs then the finding showed there were other roles besides the prevalent basic reasons. there are showing respecting, illustrating situation or thing, condition of people, illustrating what people doing, characters of people, and about activities.
\end{abstract}

Keywords - Cognitive semantics; Figurative meaning; Interpreting proverb

\section{INTRODUCTION}

Almost all nations in this world have their own proverbs because proverb is a reflection of their way of thinking, way in behaving, and any kinds of society activities that is surely alive and exist in culture. It is in line with the statement that proverbs is a realization several factors of how human's perspective in their daily life and also the accumulation from so many experiences which is inherited by the ancestors and life norms that already have been combined with religions and also culture [1].

So the proverbs that are used by society in daily life can be said as the reflection of society's cognition of experiences, point of view and observation result from the events that held around them. But as it said that generally proverb is a short sentence known by society that consists of wisdom, truth, morality and it is traditional point of view in the form of metaphor, certainty, memorable and used from generation to generation [2].

Practically we always speak and write in order to express a meaning of one kind or another. Without a capacity to express meaning, then language loses one of its essential aspects. To conquer a communication, ultimately an individual needs basic knowledge. Lose a part meaning of a sentence the consequence is getting incompletely information. Not only sentences have meanings. Even the shortest, most every day words, which we would not normally consider as containing information, like the, not, of, or even ouch!, contribute something specific to the meanings of utterances in which they occur and can thus the legitimately considered as having meanings in their own right [3].

The meanings we can express through language are infinitely more numerous, detailed and precise than those expressible through other semiotic media [3]. He adds that yet the type of meaning found in language can be seen as a subset of two broader categories of meaningfulness: the significance of human behavior in general and the meaningfulness of communication specifically. And there are also many meaningful ways of behaving which do not involve language such as shaking head, thumbs up or down.

Refer to the categories of meaningfulness - significance of human behavior and meaningfulness of communication, then how about the proverbs which sometimes arise in the middle of communication, in the middle of discourse, and so on. As far as it knows that proverb is another way to people in communication, because it sometimes inserts in the middle of the discourse, speech, bulletin, news and soon.

The scope of the study concerning to Meaning is so vast. In this study, the discussion specifically investigates Meaning in Semantics domain that is Figurative Meaning. Figurative meaning is the use of lexeme which having a meaning other than its literal meaning. For example in a phrase "panjang tangan", the phrase is not explained as a hand with certain length. But it means as a thief or people steals someone's property. Moreover, figurative meaning take places in proverbs. For example, hidup segan mati tak mau. Figurative meaning comes from figurative language. Figurative language is a conspicuous departure from what competent users of a language apprehend as the standard meaning of words, or else the standard order of words, in order to achieve some special meaning or effect [4]. So it also considered as the anomaly of a language, the anomaly of standardized language, meaning anomaly and structure anomaly of words in order to acquire certain effect or special meaning.

Responding about both examples, then it is fascinating to dig up the role of figurative meaning within proverb present for in the way they are. By applying Cognitive semantics approach as a base of revealing the mental process 
in interpreting proverbs then the finding shows whether there are other roles besides the prevalent basic reasons or not. Then if it is yes, what other roles are.

\section{RESEARCH METHOD}

This study is conducted by applying descriptive qualitative method which means to find out how a theory works in different phenomena whose data collections are in the form of words or pictures rather than numbers [5]. This study based on Semantics field and the orientation is about figurative meaning. The data of this study were words, sentences or clauses taken from the book entitled PERIBAHASA written by K.S Pamuntjak, N.S Iskandar and A.D. Madjoindo. This book has 544 pages and has 4032 proverbs. This published on 2004 and it is the latest edition since the first publication on 1946 by Balai Pustaka. This book was chosen because it was written by the old school scholars. They are productive scholar in Balai Pustaka era and already composed many literary works.

The collecting data applied the technique of documentary technique. The use of documentary methods refers to the analysis of documents that contain information about the phenomenon we wish to study. The documentary method as the techniques used to categorize, investigate, interpret and identify the limitation of physical sources, most commonly written documents whether in the private or public domain. In this case the documentary technique is the way in terms of collecting data by using the book entitled PERIBAHASA written by K.S Pamuntjak and colleagues. The researcher selected the data in the base on the need of the research. In this research the data were collected as much as $10 \%$ from the whole data in the PERIBAHASA text book, so that is 400 proverbs from 4026 proverbs. After data collection completed, the researcher analyzes them in accordance to the procedures, they are; data condensation; data display; drawing/verification conclusion [6].

\section{FINDINGS AND DISCUSSION}

The data of this study were words, sentences or clauses taken from the book entitled PERIBAHASA written by K.S Pamuntjak, N.S Iskandar and A.D. Madjoindo. This book has 544 pages and has 4032 proverbs. The data analyzed in accordance to Miles, Huberman \& Saldana procedures, they are; data condensation; data display; drawing/verification conclusion.

In first procedure, data condensation, the process refered to the process of selecting the data from the raw data that is $10 \%$ from the raw data or 4032 proverbs. So the selecting data were approximately 400 proverbs. So the selected 400 proverbs are simplified from the big number of thousand proverbs in that book. After abstracting the raw data to be 400 proverbs then we move to categorize the selecting data. They will be categorized on the base of the types of the figurative meanings in accordance of [4]. Ultimately, the drawing/verifying conclusion refers to the analyst proceeds. While getting the selected data was in accordance to the types of the figurative meaning then they will be analyzed on the base of Taylor concerning the reasons of figurative meaning realized in the way they are. They verified by elaborating with argumentation.

The research findings indicated there are another role beyond the prevalent basic reasons. There are showing respecting, illustrating situation or thing, condition of people, illustrating what people doing, characters of people, and about activities.

From 400 proverbs as the data, there were 66 figurative meanings within proverbs $(16.5 \%)$ play role in expressing a truth of experience, 55 figurative meanings within proverbs $(13.75 \%)$ play role in presenting on the importance morality, personal character and social development, 29 figurative meaning within proverbs $(7.25 \%)$ play role in presenting on advice and encouragement, 26 figurative meaning within proverbs $(6.5 \%)$ play role in presenting on warning, 13 figurative meaning within proverbs $(16.5 \%)$ play role in presenting on reproach and punishment. The rest is 212 figurative meanings within proverbs illustrate another roles, they are 2 figurative meaning within proverbs ( $0.5 \%$ ) play role in showing on respecting, 36 figurative meaning within proverbs ( $9 \%$ ) play role in illustrating situation or thing, 23 figurative meaning within proverbs ( $5.75 \%$ ) play role in illustrating people's condition, 62 figurative meaning within proverbs $(15.5 \%)$ play role in illustrating what people doing, 50 figurative meaning within proverbs $(12.5 \%)$ play role in illustrating people character and 39 figurative meaning within proverbs $(9.75 \%)$ play role in illustrating about activities.

\section{CONCLUSION}

From the finding so it can be conclude that each nation has its own proverbs, has its own roles. While the proverbs come up, they actually the reflection of what happen around us, but it packaged lovely by using figurative meaning in order to make it more worthy and memorable. The more roles found in this research show that Indonesia proverbs have the brilliant creator, eventhough we do not know who they are. How wealthy we Indonesian proverbs are.

TABLE I. ROLES OF FIGURATIVE MEANINGS WITHIN INDONESIAN PROVERBS

\begin{tabular}{|l|c|c|}
\hline \multicolumn{2}{|c|}{ Roles of Figurative Meanings within Indonesian Proverbs } \\
\hline \multicolumn{1}{|c|}{ Roles } & Number & Percentage \\
\hline Expressing a truth of experience & 66 & 16.5 \\
\hline $\begin{array}{l}\text { Presenting on the importance } \\
\text { morality, prsonalcharacter and } \\
\text { social development }\end{array}$ & 54 & 13.5 \\
\hline $\begin{array}{l}\text { Presenting on advice and } \\
\text { encouragement }\end{array}$ & 29 & 7.25 \\
\hline $\begin{array}{l}\text { Presenting on warning } \\
\text { Presenting on reproach and } \\
\text { punishment }\end{array}$ & 13 & 6.5 \\
\hline Others & 212 & 3.25 \\
\hline Total & 400 & 100 \\
\hline
\end{tabular}


Based on the Table I, it can be known that huge numbers are the role beyond of the prevalent basic roles of figurative meanings within proverbs. After analyzing the huge number then found there are $0.5 \%$ play role in showing on respecting, $9 \%$ play role in illustrating situation or thing, $5.75 \%$ play role in illustrating people's condition, $15.5 \%$ play role in illustrating what people doing, $12.5 \%$ play role in illustrating people character and $9.75 \%$ play role in illustrating about activities.

The analyzing process conducted by using the proverbs interpreting. Interpreting proverbs can be done by using source domain to target domain or by mapping the situation that is illustrated in the source domain. It is elaborate how the object conceptualized metaphorically.

Here are several examples of analyzed proverbs :

1. Berjalan pelihara kaki, berkata pelihara lidah. (P.231)

This proverbs were interpreted by mapping the situation depicted in that proverb. The figurative meaning in data 1 considered as advice due to it interprets that in speaking should remember carefully, because if it already conveyed then difficult to fix. there will be problem for the future if we talk as we wish without rethinking. So as it often mentioned that mulut mu adalah harimau mu.

\section{Takkan lari gunung dikejar, hilang kabut tampaklah} dia (P.175)

This proverbs were interpreted by mapping the situation depicted in that proverb. The figurative meaning in data 2 considered as advice due to it interprets that if it's a certain matter so don't be rushed to do it, just slow down to get a perfect result. This data suggest us not to be hurry up in doing certain thing.

\section{Kambing hitam (P.235)}

Data 3 has its figurative meaning which describes a punishment to a group of people due to their unusual behavior, so another people suspect them and don't believe them.

\section{Bagaimana bunyi gendang begitulah tarinya (P.167)}

This proverbs were interpreted by mapping the situation depicted in that proverb. The figurative meaning in data 4 illustrate that every doings will get its payback. So this is a warning concerning if we act good, so the payback will be good and vice versa.

\section{Seperti anjing dan kucing (P.27)}

This proverbs were interpreted by mapping the situation depicted in that proverb. This situation eases to find around us, while a dog meets a cat so they will make a battle. So this is a form of role in illustrating situation or thing.

From the analysis it can be considered that figurative meanings within Indonesian proverb have more roles than others. Presenting the truth of experience and illustrating what people doing become the highest number

\section{REFERENCES}

[1] A. H. Omar. "Ensiklopedi Bahasa Melayu. 2008 in N. lailatul Aqromi. "Penggunaan Kata Api dalam Peribahasa Bahasa Inggeris dan bahasa Indonesia." Unpublished

[2] B. J. Whiting. "Modern Proverbs and Proverbial Saying" in W. Mieder. "Proverbs". Greenwood Press. London. 2004

[3] N. Riemer. "Introducing Semantics". Cambridge:Cambridge University Press. 2010

[4] M. H. Abrams and G. G. Harpham. "A Glossary of Literary Terms Ninth Edition”. Boston:Wadsworth Cengage Learning. 2009

[5] R. Bogdan and S. Knopp Biklen. "Qualitative research for education.Ed.5". Boston: Pearson Education Inc. 2007

[6] M.B. Miles, B. M. Hubberman and J. Saldana. "Qualitative Data Analysis third Edition. Sage Publication. Arizona. 2014

[7] A. Taylor. "The Proverb, Proverbs, and Their Lessons" in A. Ademowo 